\title{
Performance of Rainfed Wheat Based Intercropping in Kaymore Plateau
}

\author{
S.S. Kaushik ${ }^{1 *}$ and T.D. Sharma ${ }^{2}$ \\ ${ }^{1}$ Krishi Vigyan Kendra, Dahigaon, Ahmednagar, Maharashtra-414502, India \\ ${ }^{2}$ A.S.P.G. College Lakhaoti, Bland Shahar U.P., India \\ *Corresponding author
}

A B S T R A C T

\begin{tabular}{|c|c|}
\hline Keywords & \\
\hline $\begin{array}{l}\text { Wheat, Chickpea, } \\
\text { Linseed, Mustard, } \\
\text { Intercropping and } \\
\text { row ratio. }\end{array}$ & \multirow{4}{*}{$\begin{array}{l}\text { A field experiment was conducted at Krishi Vigyan Kendra, Deendayal } \\
\text { Research Institute, Majhagawan, Satna with the objective to find out } \\
\text { compatible intercropping and row ratio with wheat. Three crops viz. } \\
\text { chickpea, linseed and mustard intercropped with wheat under rainfed } \\
\text { condition. It could be concluded that intercropping with chickpea in } 2: 2 \\
\text { row ratio was found to be significant. }\end{array}$} \\
\hline Article Info & \\
\hline $\begin{array}{l}\text { Accepted: } \\
\text { 29 June } 2017\end{array}$ & \\
\hline $\begin{array}{l}\text { Available Online: } \\
\text { 10 July } 2017\end{array}$ & \\
\hline
\end{tabular}

\section{Introduction}

Rain fed agriculture has a distinct place in Indian agriculture, occupying 67 percent of the cultivated area, contributing to 44 percent of food grains and supporting 40 percent of human and livestock population (Reddy, 2004). Most of the pulses, oilseeds and millets are confined to rain fed ecosystem, which is also grown on sizeable area under rain fed conditions. The crops of wheat, chick pea, mustard and total oilseeds are grown under rain fed conditions, respectively on $37.6,84.8$, 56.6 and 85.1 percent of their total area in the country (Gautam, 1999).

Wheat is a major staple food crop of India and is of paramount importance for food security of the country. It has been a staple food with the level of consumption largely unaffected by changes in its prices and the price of substitutes like rice, maize and millets. Pulses and oilseeds are the main crops of rain fed area. Among pulses chickpea is grown on 2.56 million hectare with $925 \mathrm{Kg} / \mathrm{ha}$ productivity (Ali and Shiv Kumar 2007). Among oilseeds, rapeseed and mustard has a great significance and contributed a lot in increasing the total oilseed production in the country during last two decades. Madhya Pradesh is a major oilseed producing state in the country. Linseed is also an important oilseed crop grown in Madhya Pradesh particularly under rain fed conditions.

The ways of increasing production are either expansion in area or improvement in productivity. In general, there is hardly any scope to bring additional area exclusively under pulses or oilseeds or even wheat as the 
demand of land for other crops will continue to rise. Thus there is only way to left is improvement in productivity of crops. Besides, other techniques, intercropping systems of growing two or more crops together on the same piece of land simultaneously may play an important role particularly under rain fed situation, where risk is more in mono cropping system.

\section{Materials and Methods}

The experiment was carried out between 2005 and 2007 at research farm of Krishi Vigyan Kendra Majhagawan, Satna, Madhya Pradesh which is situated in the Satpura and Kaymore Plateau range and lies at $24^{0} 51^{\prime} 15^{\prime \prime}$ to $24^{0} 57^{\prime}$ $30^{\prime \prime} \mathrm{N}$ latitude and $80^{\circ} 43^{\prime} 30^{\prime \prime}$ to $80^{\circ} 54^{\prime} 15^{\prime \prime} \mathrm{E}$ longitude at the elevation of $313 \mathrm{~m}$ from mean sea level. The intercrops chosen for this experiment were chickpea, linseed and mustard with three row i.e. 2:2, 4:2 and 6:2. The soil of experimental area was sandy loam in texture and shallow in depth and soil was very low in available nitrogen, low in available phosphorus and higher in available potassium. Soil class was sandy loam and reaction was almost neutral. The mean annual rainfall of the experimental area varies from $600 \mathrm{~mm}$ to $850 \mathrm{~mm}$.

\section{Results and Discussion}

\section{Growth character of wheat and intercrop}

\section{Effects of intercrops}

It is clear from the given table 1 that different intercrops could not affect the plant height of wheat significantly at earlier stages of 30DAS, but at all later stages, chickpea increased the wheat height significantly over other intercrops.

Mustard intercrop produced taller wheat plant than linseed intercropping at all stages but the margin of difference was found significant only at final stage of maturity. At maturity stage, wheat plants with chickpea intercrop attained 1.6 and 3.9 percent higher plant height than mustard and linseed intercropping, respectively on pooled basis over years. However, plant height of sole wheat, was measured 1.3, 2.9 and 5.2 percent higher than wheat with chickpea, mustard and linseed intercrops, respectively. Tomar et al., (1997) reported the same findings. The data given in (Table 2) shows that at earlier stages of 30 DAS plant height was not influenced significantly by treatments in pooled analysis at all stages and in individual years only at 60 days stage. Pooled results show that chickpea, linseed and mustard plant height was significantly higher in sole crop than in intercropping.

\section{Effect of row ratios}

Plant height of wheat, chickpea, linseed and mustard was influenced significantly by different row ratios of intercropping system in but not at 30 DAS.

Similar results have been reported by Tomar et al., (1997) and Hiremath et al., (1991).

\section{Sole v/s intercropping}

Sole wheat attained more plant height than intercropped wheat, but margin of difference was found significant at later stages of beyond 30 DAS and those too mainly in pooled data, sole wheat attained 3.1 percent higher plant height than intercropped wheat. The interaction effect of intercrops $x$ row ratios was not found significant on plant height of wheat in pooled data.

\section{Grain and straw yield of wheat and} intercrops

It is evident from table 5 that grain and straw yield of wheat and intercrops was significantly influenced by all the treatment 
factors in pooling. The interaction effect of inter-croppings $\mathrm{x}$ row ratio was found significant in case of pooled results.

\section{Effect of intercrops}

Grain and straw yield of wheat was produced significantly highest in wheat +chickpea intercropping and significantly lowest in wheat + mustard system in pooling.

In pooled results, wheat + chickpea recorded highest of 32.58q/ha grain and $45.24 \mathrm{q} / \mathrm{ha}$ straw yield of wheat (Table 1). It was found $4.22,5.19$ and $9.51,10.29 \mathrm{q} / \mathrm{ha}$ or $14.9,13$ and 41.2, 29.4 percent higher than the yields in wheat + linseed and wheat + mustard intercroppings, respectively.

However, this grain and straw yield was 7.36, $5.71 \mathrm{q} /$ ha or $18.4,12.6$ percent lower than the yield of sole wheat crop. Higher yields of wheat per unit are in sole crop than in intercropping system have also been reported by various workers like Reddy (2004), Sharma et al., (1987) Tomar et al., (1997 Srivastav and Bohra (2006).

On the basis of pooled data, yield reductions in 2:2, 4:2 and 6:2 row ratios of intercropping as compared to sole chickpea were found $7.06 \mathrm{q} / \mathrm{ha}$ or $35.8 \% 11.21 \mathrm{q} / \mathrm{ha}$ or $56.8 \%$ and 13.17 q./ha or $66.8 \%$, in linseed yield reductions in 2:2, 4:2 and $6: 2$ row ratios of intercropping were worked out as $5.53 \mathrm{q} / \mathrm{ha}$ or $45.4 \%, 7.56 \mathrm{q} / \mathrm{ha}$ or $62 \%$, and $8.78 \mathrm{q} / \mathrm{ha}$ or $72 \%$ and yield reduction in intercropping as compared to sole mustard were found $3.57 \mathrm{q} / \mathrm{ha}$ or $25.3 \% 7.0 \mathrm{q} / \mathrm{ha}$ or $49.6 \%$ and $8.72 \mathrm{q} /$ ha or $61.8 \%$, respectively in $2: 2,4: 2$ and $6: 2$ row ratios treatments respectively.

These results may be supported by the findings of Srivastav and Bohra (2006). Stover yield was produced significantly highest in sole stand of all intercrops during both years. Stover yield reduced in intercropping with each wider row ratio up to widest of 6:2 ratio. On the basis of pooled data yield reduction in intercropping as compared to sole stand were found to be $10.16 \mathrm{q} / \mathrm{ha}$ or $37.3 \%, 15.88 \mathrm{q} / \mathrm{ha}$ or $48.3 \%$, and $18.43 \mathrm{q} / \mathrm{ha}$ or $67.6 \%$ under $2: 2,4: 2$ and $6: 2$ row ratios, respectively in case of chickpea.

Such reduction in linseed were found as 9.41 $\mathrm{q} / \mathrm{ha}$ or $47.77 \%, 12.63 \mathrm{q} / \mathrm{ha}$ or $64.1 \%$, and $14.43 \mathrm{q} / \mathrm{ha}$ or $73.2 \%$ and in mustard as $8.84 \mathrm{q} / \mathrm{ha}$ or $30.4 \%, 15.22 \mathrm{q} / \mathrm{ha}$ or $52.4 \%$, and $18.16 \mathrm{q} /$ ha or $62.5 \%$, respectively.

\section{Effect of row ratio}

Grain and straw yield of wheat showed significant increase with each wider row ratio of wheat and intercrops. Thus, the yield of wheat was significantly maximized under 6:2 row ratio in all cases. Pooled results show that 6:2 row ratio produced highest of $32.93 \mathrm{q} / \mathrm{ha}$, $44.69 \mathrm{q} / \mathrm{ha}$ grain and straw yield, which was computed to be 3.74, 2.89 and 11.04, 10.93 $\mathrm{q} /$ ha or $12.8,6.9$ and $50.4,32.4$ percent higher as compared to grain yield under $4: 2$ and $2: 2$ row ratio, respectively.

\section{Sole v/s intercropping}

Sole wheat produced significantly higher grain and straw yield than intercropped wheat by the margin of $11.94,10.87 \mathrm{q} / \mathrm{ha}$ or 42.6 , 27.1 percent in pooled results. The yield reduction in intercropping as compared to wheat was found 29.9 percent against population reduction 36.1 percent.

\section{Interaction effect}

Intercropping of linseed or mustard produced significantly highest grain yield of wheat in 6:2 row ratio, but with chickpea intercrop, difference between $6: 2$ and $4: 2$ row ratio was not found significant. 
Table.1 Plant height, grain and straw yield of wheat under different treatments (Pooled data for 2 years)

\begin{tabular}{|c|c|c|c|}
\hline Treatment & Plant height $(\mathrm{cm})$ & Grain yield (q/ha) & Straw yield (q/ha) \\
\hline Intercropping & Pooled & Pooled & Pooled \\
\hline Wheat+chickpea & 98.39 & 32.58 & 45.24 \\
\hline Wheat+linseed & 94.74 & 28.36 & 40.05 \\
\hline Wheat+mustard & 96.85 & 23.07 & 34.95 \\
\hline S.Ed. + & 0.75 & 0.71 & 0.97 \\
\hline C.D. $(\mathrm{P}=0.05)$ & 1.52 & 1.44 & 1.97 \\
\hline \multicolumn{4}{|l|}{ Row ratios } \\
\hline $2: 2$ & 95.76 & 21.89 & 33.76 \\
\hline $4: 2$ & 96.8 & 29.19 & 41.8 \\
\hline $6: 2$ & 97.42 & 32.93 & 44.69 \\
\hline S.Ed. + & 0.75 & 0.71 & 0.97 \\
\hline C.D. $(\mathrm{P}=0.05)$ & NS & 1.44 & 1.97 \\
\hline \multicolumn{4}{|l|}{ Sole v/s intercropping } \\
\hline Sole crop & 99.64 & 39.94 & 50.95 \\
\hline Intercrop & 96.66 & 28 & 40.08 \\
\hline S.Ed. + & 0.97 & 0.92 & 1.26 \\
\hline C.D. $(\mathrm{P}=0.05)$ & 1.96 & 1.86 & 2.54 \\
\hline
\end{tabular}

Table.2 Plant height of intercrops chickpea, linseed and mustard $(\mathrm{cm})$ at successive crop growth Stages under different treatments (Pooled data for 2 years)

\begin{tabular}{|l|c|c|c|c|c|c|}
\hline Year of experiment & \multicolumn{7}{|c|}{ Treatments } & S.Ed. +. & C.D.(P=0.05) \\
\hline & $\begin{array}{c}\text { Sole } \\
\text { chickpea }\end{array}$ & $\mathbf{2 : 2}$ & $\mathbf{4 : 2}$ & $\mathbf{6 : 2}$ & & \\
\hline & \multicolumn{7}{|c|}{ At maturity } \\
\hline Pooled & 42.67 & 40.72 & 40.32 & 40.08 & 0.66 & 1.43 \\
\hline & Sole linseed & $\mathbf{2 : 2}$ & $\mathbf{4 : 2}$ & $\mathbf{6 : 2}$ & S.Ed. +. & C.D.(P=0.05) \\
\hline & 48.66 & 45.53 & 46.23 & 46.38 & 1.07 & 2.32 \\
\hline Pooled & $\begin{array}{c}\text { At maturity } \\
\text { mustard }\end{array}$ & $\mathbf{2 : 2}$ & $\mathbf{4 : 2}$ & $\mathbf{6 : 2}$ & S.Ed. +. & C.D.(P=0.05) \\
\hline & \multicolumn{7}{|c|}{ At maturity } \\
\hline Pooled & 146.12 & 142.11 & 142.57 & 143.5 & 2.05 & NS \\
\hline
\end{tabular}

Table.3 Grain yield of wheat (q/ha) under interaction effect of intercropping $x$ row ratio Interactions (Pooled data for 2 years)

\begin{tabular}{|c|c|c|c|c|c|}
\hline \multirow[t]{2}{*}{$\begin{array}{l}\text { Treatment } \\
\text { Intercroppings/Yield }\end{array}$} & \multicolumn{3}{|c|}{ Row ratios } & \multirow[t]{2}{*}{ S.Ed. +. } & \multirow[t]{2}{*}{ C.D. $(\mathbf{P}=\mathbf{0 . 0 5})$} \\
\hline & $2: 2$ & $4: 2$ & $6: 2$ & & \\
\hline Wheat+chickpea/Grain & 28.3 & 33.69 & 35.75 & - & - \\
\hline Wheat+chickpea/Straw & 42.33 & 46.50 & 46.90 & - & - \\
\hline Wheat+linseed/Grain & 21.22 & 29.63 & 34.24 & 1.24 & 2.5 \\
\hline Wheat+linseed/Straw & 33.06 & 42.02 & 45.07 & 1.69 & 3.40 \\
\hline Wheat+mustard/Grain & 16.16 & 24.25 & 28.79 & - & - \\
\hline Wheat+mustard/Straw & 25.88 & 36.88 & 42.11 & - & - \\
\hline
\end{tabular}


Table.4 Grain and straw yield (q/ha) of intercrops under different treatments

\begin{tabular}{|c|c|c|c|c|c|c|}
\hline \multirow{3}{*}{ Yield } & \multicolumn{4}{|c|}{ Treatments } & \multirow[t]{2}{*}{ S.Ed. + } & \multirow[t]{2}{*}{ C.D. $(\mathrm{P}=0.05)$} \\
\hline & Sole crop & $2: 2$ & $4: 2$ & $6: 2$ & & \\
\hline & \multicolumn{6}{|c|}{ Chickpea yield } \\
\hline Grain & 19.73 & 12.67 & 8.52 & 6.56 & 0.56 & 1.22 \\
\hline \multirow[t]{2}{*}{ Straw } & 27.26 & 17.1 & 11.38 & 8.83 & 0.65 & 1.41 \\
\hline & \multicolumn{6}{|c|}{ Linseed yield } \\
\hline Grain & 12.19 & 6.66 & 4.63 & 3.41 & 0.29 & 0.64 \\
\hline \multirow[t]{2}{*}{ Straw } & 19.71 & 10.3 & 7.08 & 5.28 & 0.45 & 0.97 \\
\hline & \multicolumn{6}{|c|}{ Mustard yield } \\
\hline Grain & 14.11 & 10.54 & 7.11 & 5.39 & 0.32 & 0.69 \\
\hline Straw & 29.06 & 20.22 & 13.84 & 10.9 & 0.63 & 1.38 \\
\hline
\end{tabular}

On the other way, 2:2 and 4:2 row ratio produced highest wheat yield with chickpea intercropping, but under 6:2 row ratio difference between chickpea or linseed intercropping in wheat was not significant. But 6:2 and 4:2 row ratio are being at par with other produced significantly higher straw yield than in 2:2 row ratio under wheat + chickpea and wheat + linseed inter-croppings, but under wheat + mustard system 6:2 row ratio produced significantly highest straw yields. On the other way 2:2 and 4:2 row ratio recorded significantly highest straw yield with wheat + chickpea intercropping system but at the same time 6:2 row ratio, linseed also remained at par with chickpea intercropping system. However, the combination of wheat +chickpea in 6:2 row ratio being at pat with wheat +chickpea in $4: 2$ ratio and wheat + linseed in 6:2 row ratio, produced significantly higher straw yield than remaining treatment combination.

The growth character plant height was recorded significantly higher in wheat +chickpea than other intercrops, among which mustard attained lower values than intercropping. Plant height of mustard and linseed at maturity was found significantly higher in sole stand than intercroppings (Table 2). It might be due to more competition between plants for solar radiation under dense population in sole stand. Trend was found similar in mustard also, but differences were not significant. The better growth of wheat with chickpea intercropping might be due to beneficial effect of chickpea on wheat in association, where symbiotic $\mathrm{N}$ fixation by chickpea roots may be transferred for utilization of wheat. Besides, favorable influence of chickpea root excretion on associated wheat might improve the growth of wheat. On the other hand, allelopathic compound released by linseed plants in root zone and in environment may have harmful effects on associated wheat plants, which resulted in poor growth of wheat plants. The adverse effect of mustard on wheat growth can be ascribed to the greater competition exerted by dominant mustard crop for light, space and nutrients. Being taller and profused branching mustard plant had much shading effect on wheat, which may restrict the proper growth of wheat crop. Similar findings have been reported by Willey (1979).

\section{Beneficial effect of chickpea on wheat growth}

Growth characters of wheat significantly maximized in 2:2 row ratio with chickpea intercropping, whereas effect of row ratio was not significant with linseed in all cases. In case of mustard intercropping 6:2 row ratio gave higher values of wheat growth indices. Improvement in wheat growth under 2:2 ratio of wheat +chickpea might be due to beneficial effect of chickpea on whole population of 
wheat through symbiotic $\mathrm{N}$ fixation and complimentary use of resources by component crops. Maximizing intercropping advantages is a matter of maximizing the degree of complimentarity between the component crops. Better wheat growth under 6:2 row ratio with mustard might be due to the fact that only $33.3 \%$ population of wheat, was affected by mustard intercrop against $100 \%$ and $50 \%$ in row ratios of $2: 2$ and $4: 2$, respectively. Mustard rows imposed competition for light, space and nutrients on wheat grown in vicinity. Mustard due to shading effect on side rows of wheat, may reduced the growth of wheat plants. Nonsignificant effect of row ratios in wheat +linseed intercropping on wheat growth might be ascribed to environmental allelopathic effect of linseed on wheat, which perhaps affected wheat plants under different row ratios in similar way. The grain and straw yield per unit area were obtained significantly higher in sole crop of wheat than in intercropping system. These higher yields are attributed mainly to higher production of wheat in sole stand than in intercropping, as the intercropping was followed in replacement series. Not only those but other research workers observed yield reduction of main crop in intercropping system that its pure stand particularly in replacement series of intercropping system. It is usual phenomenon that when plant population is reduced than optimum, yield per unit will certainly reduces. Thus it is not valid for comparison of intercropping treatments within themselves and between sole cropping and intercropping system comparison.

Among inter-croppings, chickpea produced significantly highest and mustard produced significantly lowest grain and straw yields of wheat (Table 1). Chickpea being dwarf statured did not cause much competition for space and solar radiation, and being legume provided some of the symbiotic $\mathrm{N}$ for wheat utilization, which ultimately produced higher wheat yield than other inter-croppings. Lowest wheat with mustard intercrop might be due to greater competition exerted by dominant mustard crop for light, space and nutrients. Greater canopy of mustard, intercepted greater part of light, thereby putting wheat crop to a disadvantage. The lower yield of wheat with linseed than chickpea intercropping might be due to allelopathic effect of chickpea (Table 1). Allelopathic compounds can have important effects on other crop plants, when planted in association or mixtures. Interaction effects of intercrops $\mathrm{x}$ row ratio was found significant on grain yield of wheat, which showed that intercropping of linseed or mustard produced significantly maximum wheat yield with $6: 2$ row ratio, but in chickpea intercropping, 4:2 row ratio yielded at par with $6: 2$ row ratio (Table 3). It might be the combined effect of leguminous effect of chickpea on more wheat rows than $6: 2$ row ratio and higher wheat population under $4: 2$ ratio than $2: 2$ row ratio. Seed yield of all intercrops was produced significantly maximum under sole cropping and reduced significantly with each wider ratio of intercropping, thus minimized in 6:2 row ratio in all cases (Table 4).

It could be concluded from the findings of the above experiment that the row ratio of $2: 2$ for wheat +chickpea and 6:2 for wheat +linseed or mustard were found suitable for higher productivity and production of crops and the intercropping system of wheat + chickpea in any of the row ratio produced significantly higher yield (44.16-46.04q/ha) than sole wheat. Not only this, wheat + linseed or mustard in 2:2 row ratio produced significantly lesser (35.86 and $35.14 \mathrm{q} / \mathrm{ha}$ ) yield then sole wheat.

\section{References}

Ali, M. and Shivkumar. 2007. Pulses: good options for rain fed areas. The Hindu Survey of Indian Agriculture. pp. 39-41. 
Gautam, R.C.1999. Advances in dryland agriculture in India. Proceedings of Training Programme on Advances in Dry land Agriculture, held on Aug

26-29, 1999, at C.S. Azad University of Agriculture and technology, Kanpur, pp 65-74.

Hiremath, S.M., Chittapur, B.M. and Hosmani, M.M.1991. Wheat (Triticum aestivum) and linseed (Linum usitatissimum) intercropping system in

Northern, Karnataka. Indian Journal of Agronomy 36 (Suppl): 18:22.

Reddy, S.R. 2004. Cropping systems, resource use and plant interaction: competitive relationships. Principles of Crop Production. Kalyani, Publishers, New Delhi. pp. 531-532.
Srivastav, R.K. and Bohra, J.S. 2006. Performance of wheat (Triticum aestivum), and Indian mustard (Brassica juncea) intercropping in relation to row ratio, Indian mustard variety and fertility levels. Indian

Journal of Agronomy 51(2): 107-111.

Tomar, S.K., Singh, H.P. and Ahlawat, I.P.S.1997. Dry matter accumulation and $\mathrm{N}$ uptake in wheat (Triticum aestivum) based intercropping systems as affected by $\mathrm{N}$ fertilizer. Indian Journal of Agronomy 42 (1): 33-37.

Willey, R.W.1979. Intercropping; its importance and research needs I Competition and yield advantages. Field Crops Abstracts 32(2): 73-85

\section{How to cite this article:}

Kaushik, S.S. and Sharma, T.D. 2017. Performance of Rainfed Wheat Based Intercropping in Kaymore Plateau. Int.J.Curr.Microbiol.App.Sci. 6(7): 2619-2625. doi: https://doi.org/10.20546/ijcmas.2017.607.369 